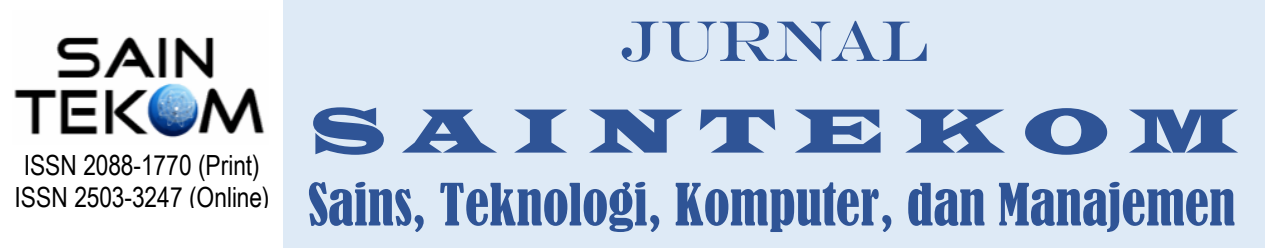

\title{
DESAIN MODEL FUZZY-TSUKAMOTO UNTUK PENENTUAN KUALITAS BUAH PEPAYA CALIFORNIA (CARICA PAPAYA L.) BERDASARKAN BENTUK FISIK
}

\author{
Muhammad Ezar Al Rivan ${ }^{1}$, Angella Octavia ${ }^{2}$ dan Irvan Wijaya ${ }^{3}$ \\ ${ }^{1,2,3)}$ Teknik Informatika STMIK Global Informatika MDP \\ Jalan Rajawali No.14 Palembang \\ Email: meedzhar@mdp.ac.id, angellaoctavia97@gmail.com, \\ irvanchou@gmail.com
}

\begin{abstract}
Papaya easily found in the local market with a relatively cheap price, adequate nutrient and vitamin content. The quality of California papaya can be measured by size, color and defect. This research discusses the topic of fuzzy model design regarding the measured of the quality of papaya using fuzzy tsukamoto with input variables major axis and minor axis as size, red and green intensity as color, and defect determined by rotten surface. Size, color and defect are variables along with the output as a result of determining the quality of California papaya. Based on the tests that have been carried out, the results of the quality are $75 \%$.
\end{abstract}

Keyword : fuzzy, tsukamoto, quality

\section{ABSTRAK}

Pepaya mudah ditemukan di pasar lokal dengan harga yang relatif murah, kandungan nutrisi dan vitamin yang memadai. Kualitas pepaya california dapat diukur dari ukuran, warna dan cacatnya. Penelitian ini membahas topik perancangan model fuzzy mengenai pengukuran kualitas buah pepaya menggunakan fuzzy tsukamoto dengan input variabel sumbu mayor dan sumbu minor sebagai ukuran, intensitas warna merah dan hijau, dan defect ditentukan oleh permukaan busuk. Ukuran, warna dan kecacatan merupakan variabel beserta output sebagai hasil penentuan kualitas pepaya california. Berdasarkan pengujian yang telah dilakukan didapatkan hasil kualitas $75 \%$.

Kata kunci : fuzzy, tsukamoto, kualitas

\section{PENDAHULUAN}

Buah pepaya merupakan buah yang sering dijual di pasar lokal dan merupakan bisnis yang sangat menguntungkan, baik bagi petani maupun pedagang (Bakar and
Ratnawati, 2017). Di Indonesia, terdapat 3 jenis pepaya yang ada, yaitu pepaya Bangkok, pepaya Hawai dan pepaya California. Pepaya California paling sering dijual ataupun dijumpai di pasaran. Buah pepaya California 
merupakan hasil pemuliaan yang dilakukan oleh Pusat Kajian Buah Tropika (PKBT)-IPB yang disebut dengan IPB 9. Menurut (Usmayani et al, 2015) tanaman pepaya varietas California merupakan salah satu jenis pepaya yang sedang digandrungi dan mulai banyak dikebunkan para petani pada saat ini karena sangat menjanjikan keuntungan. Pepaya California ini memiliki sifat dan keunggulan tersendiri yaitu buahnya tidak terlalu besar dengan bobot $0,8-1,5 \mathrm{~kg} / \mathrm{buah}$, berkulit hijau tebal dan mulus, berbentuk lonjong, buah matang berwarna kuning, rasanya manis, daging buah kenyal dan tebal. Dalam menentukan kualitas buah pepaya, dapat ditentukan dengan salah satu metode seperti Fuzzy Logic dan Pengolahan Citra Digital. Logika Fuzzy diperkenalkan oleh Lotfi Zadeh dari Universitas California, Berkeley pada 1965 (Sutojo et al, 2011). Fuzzy Logic adalah peningkatan dari logika Boolean yang berhadapan dengan konsep kebenaran sebagian (Sutojo et al, 2011). Pengolahan citra digital (Digital Image Processing) adalah sebuah disiplin ilmu yang mempelajari tentang teknik-teknik mengolah citra. Citra adalah suatu gambaran atau kemiripan dari suatu objek. Citra analog tidak dapat direpresentasikan dalam komputer, sehingga tidak bisa diproses oleh komputer secara langsung. Agar bisa diproses di komputer, citra analog harus dikonversi menjadi citra digital. Citra digital adalah citra yang dapat diolah oleh komputer (Andono and Sutojo, 2017)

Pada penelitian yang dilakukan oleh (Syakry and Mulyadi, 2013) tentang penentuan tingkat kematangan buah pepaya Callina berdasarkan kandungan nilai warna menggunakan pengolahan citra dengan citra RGB dilakukan untuk mencari tingkat kematangan pepaya yang dibagi menjadi 3 bagian, yaitu matang mentah, matang mengkal, dan matang penuh. Hasil penelitian ini mampu memberikan informasi tentang data piksel di mana pepaya matang mentah nilai merah (red) tidak mendominasi yakni 7,785495, nilai hijau (green) menjadi nilai tertinggi yakni 10,23922, pada kondisi matang mengkal terlihat bahwa komposisi warna merah dan warna hijau nilai rata-ratanya seimbang bahkan bisa dikatakan sama yakni 12,56288 dan 12,12431, sedangkan kondisi matang penuh nilai rata-rata merah menjadi lebih dominan jika dibandingkan dengan hijau yakni 24,111901 untuk merah dan 13,70812 untuk hijau. Pada penelitian lain yang dilakukan oleh 
(Syakry et al, 2015) mengenai klasterisasi nilai citra RGB buah pepaya madu berdasarkan mutu menggunakan Fuzzy C-Means (FCM) Clustering menggunakan citra warna RGB dalam penentuan mutu buah pepaya madu. Hasil penelitian ini mampu mengklaterisasi citra buah pepaya Callina dengan baik sesuai dengan nilai untuk kondisi matang mentah $\mathrm{R}<\mathrm{GB}$ yakni $\mathrm{R}=9.5825, \mathrm{~GB}=16.8833$ dengan fungsi nilainya 131.621937, kondisi matang mengkal $\mathrm{R}=\mathrm{GB}$ yakni $\mathrm{R}=17.6735, \mathrm{~GB}=17.2993$ dengan fungsi nilainya 249.712915, kondisi matang matang $\mathrm{R}>\mathrm{GB}$ yakni $\mathrm{R}=$ 24.6697, $\mathrm{GB}=16.6703$ dengan fungsi nilainya 358.783473. Pada penelitian yang dilakukan (Sugiyanto and Wibowo, 2015) juga melakukan penentuan tingkat kematangan pepaya (Carica Papaya L). Pada penelitian yang dilakukan (Prahara and Sela, 2016) metode LVQ digunakan untuk menentukan kematangan pepaya (Carica Papaya L)

Pada penelitian lain yang dilakukan oleh (Pandey et al, 2014) yang berjudul A Novel Non-Destructive Grading method for Mango (Mangifera Indica L.) using Fuzzy Expert System membahas dua bagian, yaitu memilih mangga yang sehat kemudian mengklasifikasikannya kategori matang atau mentah dan tentang tingkatan mangga berdasarkan ukuran. Dalam membedakan jenis mangga sehat atau sakit digunakan ruang warna CIELab untuk melakukan ekstraksi fitur warna untuk membedakan warna. Untuk fitur ukuran, dihitung menggunakan bentuk elips untuk mengklasifikasikan ke dalam nilai yang berbeda. Hasil penelitian ini menunjukkan akurasi sebesar 97,47\%. Selain itu pada penelitian untuk menentukan mutu pepaya telah dilakukan oleh (Al Rivan and Suherman, 2020). Pada penelitian tersebut menggunakan fuzzy Mamdani dan mendapat hasil secara rata-rata $80 \%$ sampai $83 \%$

Fuzzy Tusukamoto digunakan oleh (Bon and Utami, 2016) untuk menentukan pengambilan keputusan rencana produksi crude oil. Selain itu (Mazenda et al, 2014) menggunakan fuzzy Tsukamoto untuk sistem pendukung keputusan penentuan kualitas air. Pada penelitian (Sari and Mahmudy, 2015) fuzzy Tsukamoto digunakan untuk menentukan kelayakan calon pegawai. Selain itu fuzzy Tsukamoto telah digunakan untuk menentukan kualitas singkong seperti yang dilakukan oleh (Murdianingsih and Utomo, 2016). 
Penelitian - penelitian sebelumnya sudah banyak menerapkan berbagai macam metode dalam penentuan kualitas objek. Dalam penelitian ini dilakukan dengan membangun model fuzzy-tsukamoto dalam penentuan kualitas buah pepaya California.

\section{METODE}

Penelitian dilakukan secara bertahap hingga mencapai suatu hasil yang diinginkan. Penelitian ini dilakukan dengan tahapan identifikasi masalah, studi literatur, pengumpulan data, perancangan sistem, membangun sistem, menguji perangkat lunak, implementasi sistem, evaluasi sistem. Pada tahap melakukan perancangan sistem dalam proses penentuan sistem dalam proses penelitian mengenai kualitas buah pepaya seperti pada Gambar 1.

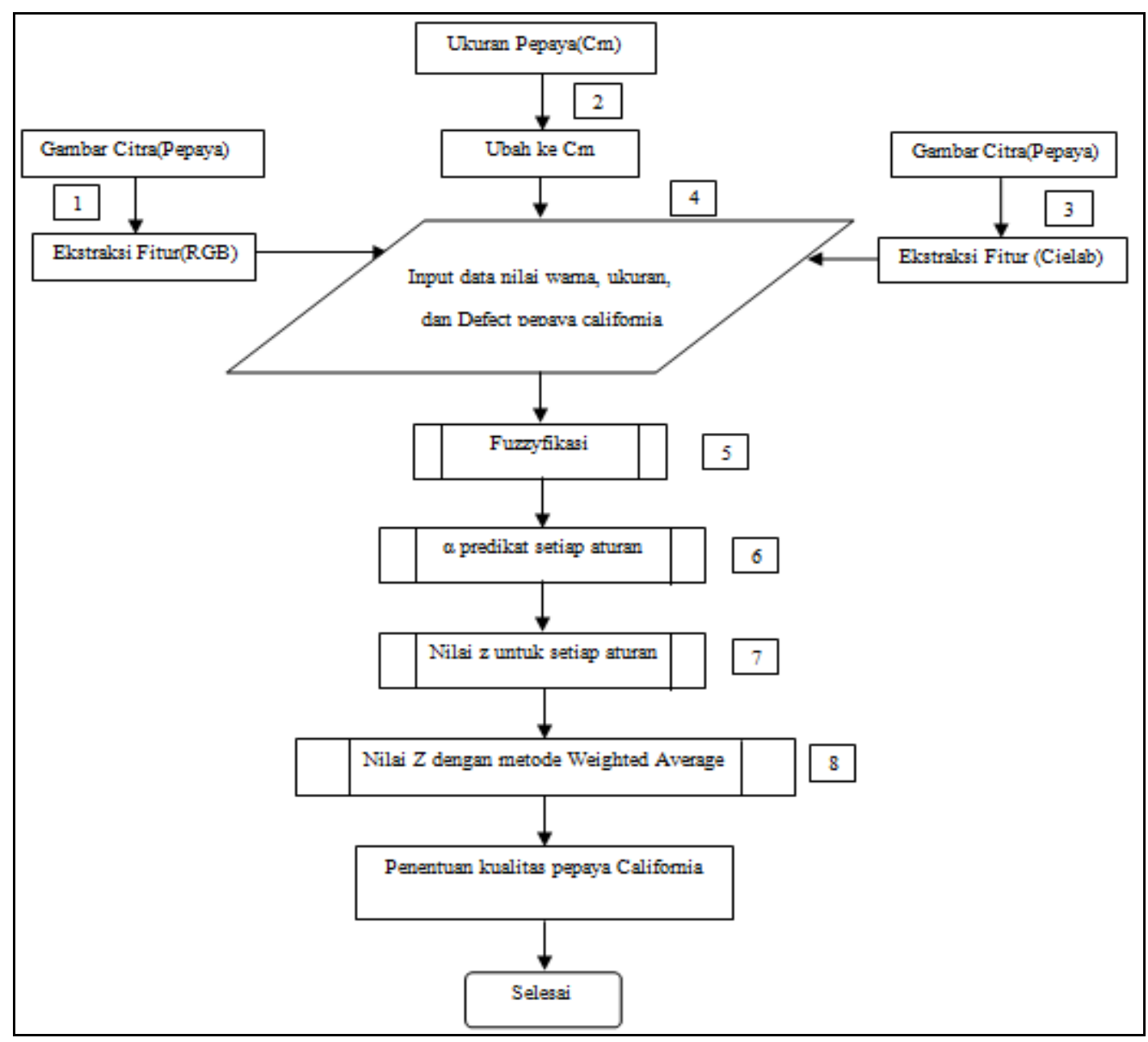

Gambar 1. Diagram Alir Proses Penentuan Kualitas Pepaya

Gambar citra pepaya akan di ekstraksi menggunakan ruang warna
RGB. Pada proses ekstraksi tidak dilakukan preprocessing. Citra pepaya 
yang digunakan merupakan keseluruhan semua permukaan kulit pepaya sehingga semua bagian dalam citra akan digunakan. Citra Ruang warna R (red) dan $\mathrm{G}$ (green) akan diambil dalam proses desain model fuzzy, untuk mencari ukuran papaya, digunakan mayor axis dan minor axis sehingga mendapatkan ukuran dalam satuan piksel. Mayor axis sebagai panjang buah dan minor axis sebagai lebar buah. Mayor axis dan Minor axis dihitung dari citra kemudian disesuaikan dengan hasil pengukuran menggunakan alat ukur. Satuan piksel kemudian diubah kedalam satuan Centimeter $(\mathrm{cm})$ dengan 1 pixel $=0.0265 \mathrm{~cm}$, ruang warna CIELab akan digunakan untuk membedakan warna yang digunakan untuk mencari nilai dari defect pada buah papaya, kemudian nilai yang didapatkan dari ruang warna RGB, CIELab dan nilai piksel akan digunakan pada fuzzy Tsukamoto, pada tahapan fuzzyfikasi, akan dibagi kedalam 5 kriteria, yaitu nilai R (red), G (green), defect, panjang buah, dan lebar buah, kemudian akan dilakukan tahap pembentukan rule berdasarkan dari 5 kriteria tersebut, setelah aturan dibentuk, kemudian setiap aturan akan dicari nilai z, setelah nilai z untuk setiap aturan didapatkan, selanjutnya akan dihitung nilai $\mathrm{Z}$ dengan menggunakan Weighted Average.
1. Variabel Input

Variabel input yang digunakan adalah variabel ukuran yang meliputi mayor axis dan minor axis, defect, Red dan Green.

a. Mayor axis

Grafik mayor axis diberikan dua parameter yaitu pendek dan panjang, dengan pendek dari 0 $20 \mathrm{~cm}$, sedangkan panjang adalah 15 - $35 \mathrm{~cm}$. Penentuan pendek dan panjang diperoleh dari pakar. Ukuran panjang atau pendek didapat dari hasil pengukuran menggunakan alat ukur pada pepaya utuh kemudian disesuaikan pada panjang yang dihitung dari citra pepaya. Grafik fungsi himpunan fuzzy dapat dilihat pada Ganbar 2.

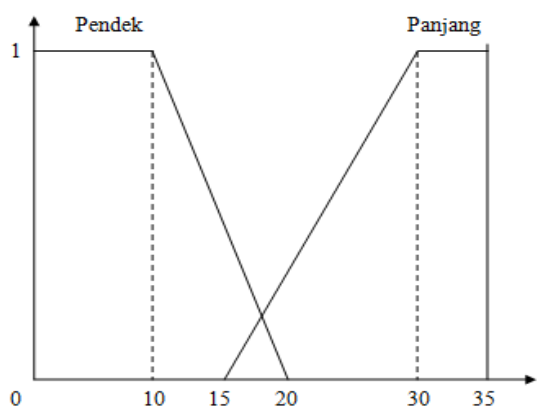

Gambar 2. Grafik Himpunan Fuzzy Mayor Axis

Fungsi Keanggotaan :

$\mu$ Pendek (a)

$$
=\left\{\begin{array}{c}
1 ; x \leq 10 \\
\frac{20-x}{20-10} ; 10 \leq x \leq 20 \\
0 ; x \geq 20
\end{array}\right.
$$


$\mu$ Panjang (a)

$$
=\left\{\begin{array}{c}
0 ; x \leq 15 \\
\frac{x-15}{30-15} ; 15 \leq x \leq 30 \\
1 ; x \geq 30
\end{array}\right.
$$

Variabel himpunan fuzzy beserta nilai domainnya dapat dilihat pada Tabel 1.

Tabel 1 Range untuk mayor axis

\begin{tabular}{|l|c|}
\hline Himpunan & Nilai \\
\hline Pendek & 0 - 20 \\
\hline Panjang & $15-35$ \\
\hline
\end{tabular}

\section{b. Minor Axis}

Grafik minor axis diberikan dua parameter yaitu pendek dan panjang, dengan pendek dari 0 $10 \mathrm{~cm}$, sedangkan panjang adalah 9 - $15 \mathrm{~cm}$. Penentuan panjang dan pendek diperoleh dari pakar. Ukuran panjang dan atau pendek didapat dari hasil pengukuran menggunakan alat ukur pada pepaya utuh. Grafik fungsi himpunan fuzzy dapat dilihat pada Ganbar 3

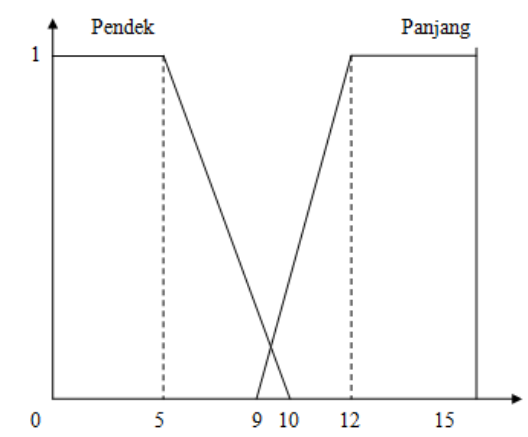

Gambar 3 Grafik Himpunan Fuzzy Minor Axis
Fungsi Keanggotaan :

$$
\begin{aligned}
& \mu \text { Pendek (b) } \\
& =\left\{\begin{array}{l}
1 ; x \leq 5 \\
\frac{10-x}{10-5} ; 5 \leq x \leq 10 \\
0 ; x \geq 10
\end{array}\right.
\end{aligned}
$$

$\mu$ Panjang (b)

$$
=\left\{\begin{array}{c}
0 ; x \leq 9 \\
\frac{x-9}{12-9} ; 9 \leq x \leq 12 \\
1 ; x \geq 12
\end{array}\right.
$$

Variabel himpunan fuzzy beserta nilai domainnya dapat dilihat pada Tabel 2.

Tabel 2 Range untuk minor axis

\begin{tabular}{|c|c|}
\hline Himpunan & Nilai \\
\hline Pendek & $\mathbf{0}-\mathbf{1 0}$ \\
\hline Panjang & $\mathbf{9}-15$ \\
\hline
\end{tabular}

\section{c. Defect}

Grafik Defect diberikan tiga parameter yaitu sedikit, sedang, dan banyak dengan rentang sedikit antara $0-25 \%$, sedangkan skala rentang sedang antara $20-60 \%$ dan rentang banyak dengan skala 55 100\%. Defect diperoleh dengan cara mengubah citra RGB ke CieLAB dan black and white (hitam dan putih). Maka didapat pixel hitam dan putih yang mana pixel putih merupakan bagian yang mengalami defect. Persentase dihitung berdasarkan banyaknya pixel putih terhadap keseluruhan pixel di citra 
pepaya. Gambar 4 menyatakan grafik defect dengan memberikan nilai berupa skala 0 sampai 100 , beserta fungsi keanggotaannya.

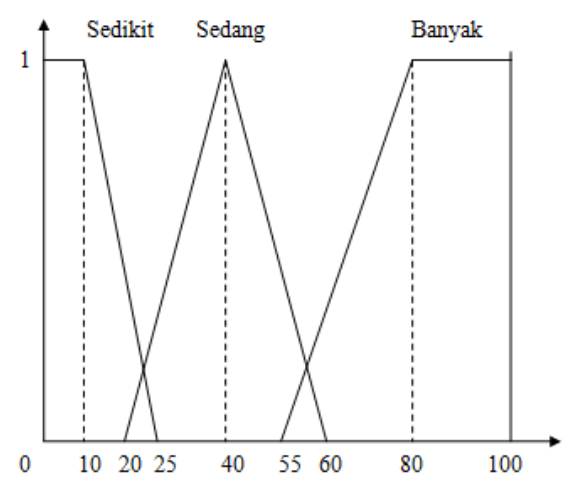

Gambar 4 Grafik Himpunan Fuzzy Defect

Fungsi Keanggotaan :

$\mu$ Sedikit (c)

$=\left\{\begin{array}{c}1 ; x \leq 10 \\ \frac{25-\mathrm{x}}{25-10} ; 10 \leq x \leq 25 \\ 0 ; x \geq 25\end{array}\right.$

$\mu$ Sedang (c)

$$
=\left\{\begin{array}{c}
0 ; x \leq 20 \text { atau } x \geq 60 \\
\frac{x-20}{40-20} ; 20 \leq x \leq 40 \\
\frac{60-x}{60-40} ; 40 \leq x \leq 60
\end{array}\right.
$$

$\mu$ Banyak (c)

$$
=\left\{\begin{array}{c}
0 ; x \leq 55 \\
\frac{x-55}{80-55} ; 55 \leq x \leq 80 \\
1 ; x \geq 80
\end{array}\right.
$$

Variabel himpunan fuzzy beserta nilai domainnya dapat dilihat pada Tabel 3.

Tabel 3 Range untuk Defect

\begin{tabular}{|l|c|}
\hline Himpunan & Nilai \\
\hline Sedikit & 0 - 25 \\
\hline Sedang & $\mathbf{2 0}-\mathbf{6 0}$ \\
\hline Banyak & $\mathbf{5 5}-\mathbf{1 0 0}$ \\
\hline
\end{tabular}

d. Red and Green

Grafik Red diberikan tiga parameter yaitu sedikit, sedang, dan dominan dengan rentang sedikit antara 80 sampai 120 dan rentang sedang antara 110 sampai 170 , sedangkan skala rentang dominan antara 160 sampai 255. Red dan Green didapat dengan menghitung rata-rata pixel Red dan Green dari citra pepaya. Gambar 5 menyatakan grafik Red, dan grafik Green pada Gambar 6 dengan rentang sedikit 100 sampai 160, skala sedang antara 150 sampai 190 dan dominan antara 180 sampai 255 , beserta fungsi keanggotaannya.

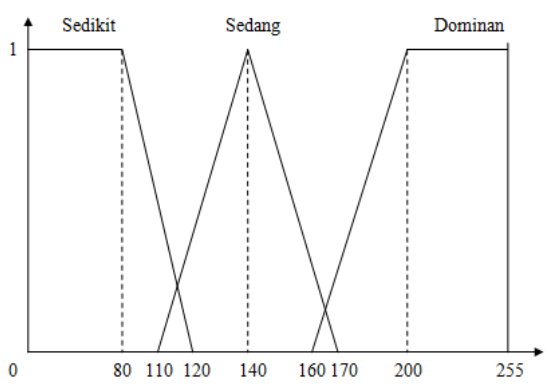

Gambar 5 Grafik Himpunan Fuzzy Red

Fungsi Keanggotaan :

$\mu$ Sedikit (d)

$$
=\left\{\begin{array}{c}
1 ; x \leq 80 \\
\frac{120-\mathrm{x}}{120-80} ; 80 \leq x \leq 120(8) \\
0 ; x \geq 120
\end{array}\right.
$$


$\mu$ Sedang (d)

$$
=\left\{\begin{array}{l}
0 ; x \leq 110 \text { atau } x \geq 170 \\
\frac{x-110}{140-110} ; 110 \leq x \leq 140 \\
\frac{170-x}{170-140} ; 140 \leq x \leq 170
\end{array}(9)\right.
$$

$\mu$ Dominan (d)

$$
=\left\{\begin{array}{c}
0 ; x \leq 160 \\
\frac{x-160}{200-160 ;} 160 \leq x \leq 200(10) \\
1 ; x \geq 200
\end{array}\right.
$$

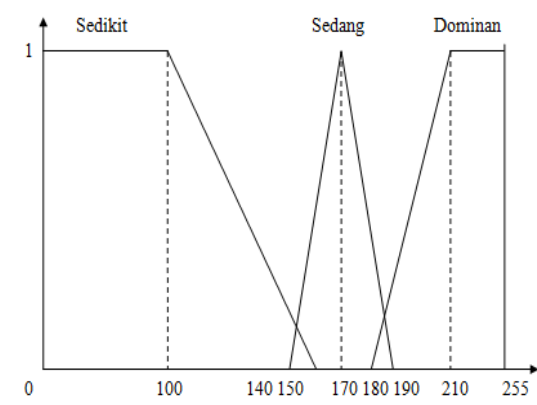

Gambar 6 Grafik Himpunan Fuzzy

$$
\text { Green }
$$

Fungsi Keanggotaan:

uSedikit (e)

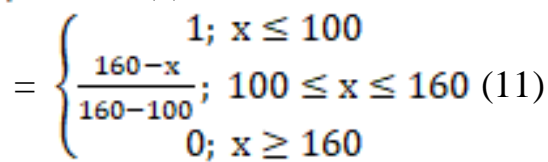

$\mu$ Sedang (e)

$$
=\left\{\begin{array}{l}
0 ; \mathrm{x} \leq 150 \text { atau } \mathrm{x} \geq 190 \\
\frac{\mathrm{x}-150}{170-150} ; 150 \leq \mathrm{x} \leq 170 \\
\frac{190-\mathrm{x}}{190-170} ; 165 \leq \mathrm{x} \leq 190
\end{array}(12)\right.
$$

$\mu$ Dominan (e)

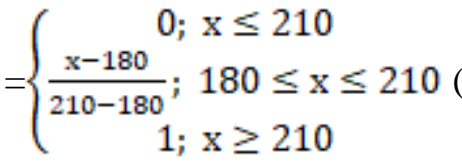

Variabel himpunan fuzzy beserta nilai domainnya dapat dilihat pada Tabel 4.
Tabel 4 Range untuk Red dan

Green

\begin{tabular}{|l|c|c|}
\hline Himpunan & Red & Green \\
\hline Sedikit & $\mathbf{0}-\mathbf{1 2 0}$ & $\mathbf{0}-\mathbf{1 6 0}$ \\
\hline Sedang & $\mathbf{1 1 0}-\mathbf{1 7 0}$ & $\mathbf{1 5 0}-\mathbf{1 9 0}$ \\
\hline Dominan & $\mathbf{1 6 0}-\mathbf{2 5 5}$ & $\mathbf{1 8 0}-\mathbf{2 5 5}$ \\
\hline
\end{tabular}

2. Variabel Output

Variabel output berupa hasil penentuan kualitas buah pepaya yang menentukan dari warna, ukuran dan defect dengan parameter yang digunakan pada variabel output meliputi jelek, sedang dan bagus, dimana diberikan opsional berupa skala mulai dari 0 sampai 10 beserta fungsi keanggotaannya dapat dilihat pada Gambar 7. Penentuan kriteria jelek, sedang dan bagus dilakukan oleh 1 orang pakar.

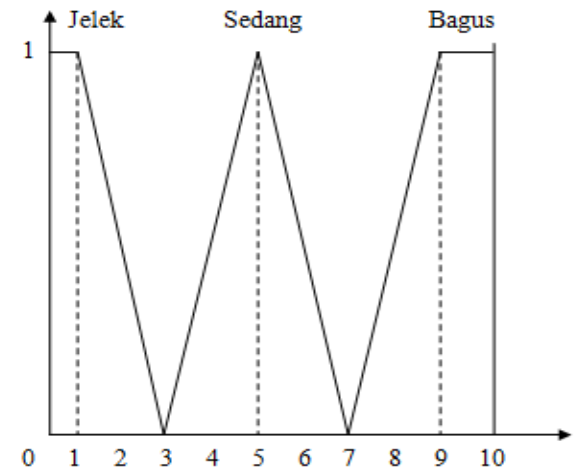

Gambar 7 Grafik Himpunan Fuzzy Hasil Penentuan Kualitas Buah Pepaya California

Fungsi Keanggotaan: $\mu$ Jelek (z)

$$
=\left\{\begin{array}{c}
1 ; x \leq 1 \\
\frac{3-x}{3-1} ; 1 \leq x \leq 3 \\
0 ; x \geq 3
\end{array}\right.
$$


$\mathrm{SSedang}(\mathrm{z})$

$$
=\left\{\begin{array}{c}
0 ; x \leq 3 \text { atau } x \geq 7 \\
\frac{x-3}{5-3} ; 3 \leq x \leq 5 \\
\frac{7-x}{7-5} ; 5 \leq x \leq 7
\end{array}\right.
$$

$\mu \operatorname{Bagus}(\mathrm{z})$

$$
=\left\{\begin{array}{c}
0 ; x \leq 9 \\
\frac{x-7}{9-7} ; 7 \leq x \leq 9 \\
1 ; x \geq 9
\end{array}\right.
$$

Variabel himpunan fuzzy beserta nilai domainnya dapat dilihat pada Tabel 5 .

Tabel 5 Range kualitas pepaya

\begin{tabular}{|l|c|}
\hline \multicolumn{1}{|c|}{ Himpunan } & Nilai \\
\hline Jelek & $\mathbf{0}$ - 3 \\
\hline Sedang & $\mathbf{3}-\mathbf{7}$ \\
\hline Bagus & $\mathbf{7 ~ - 1 0}$ \\
\hline
\end{tabular}

\section{HASIL DAN PEMBAHASAN}

Tabel 6 menjelaskan hasil kualitas buah pepaya California yang menampilkan perbandingan hasil sistem dan hasil pakar yang merupakan hasil kualitas buah pepaya California. Hasil sistem merupakan hasil penentuan kualitas menggunakan aplikasi Matlab dan hasil pakar merupakan hasil penentuan kualitas berdasarkan data pakar. Berdasarkan pengujian yang telah dilakukan, diperoleh hasil yang menyatakan tingkat akurasi penentuan kualitas sebesar $75 \%$.

Tabel 6 Hasil Penentuan Kualitas Buah Pepaya California

\begin{tabular}{|c|c|c|c|c|c|c|c|c|c|}
\hline No & Nama & Red & Green & $\begin{array}{c}\text { Defect } \\
(\text { persen })\end{array}$ & $\begin{array}{c}\text { Mayor } \\
(\mathbf{c m})\end{array}$ & $\begin{array}{c}\text { Minor } \\
(\mathbf{c m})\end{array}$ & $\begin{array}{c}\text { Hasil } \\
\text { Sistem }\end{array}$ & $\begin{array}{c}\text { Hasil } \\
\text { Pakar }\end{array}$ & $\begin{array}{c}\text { Ketera- } \\
\text { ngan }\end{array}$ \\
\hline 1 & Pepaya01 & 146 & 170 & 23 & 20 & 9 & Bagus & Bagus & Sama \\
\hline 2 & Pepaya02 & 186 & 171 & 28 & 19 & 9 & Jelek & Jelek & Sama \\
\hline 3 & Pepaya03 & 178 & 185 & 28 & 25 & 12 & Jelek & Bagus & Beda \\
\hline 4 & Pepaya04 & 170 & 148 & 15 & 25 & 12 & Bagus & Jelek & Beda \\
\hline 5 & Pepaya05 & 199 & 175 & 31 & 23 & 11 & Jelek & Jelek & Sama \\
\hline 6 & Pepaya06 & 172 & 186 & 7 & 36 & 23 & Bagus & Bagus & Sama \\
\hline 7 & Pepaya07 & 204 & 152 & 7 & 28 & 18 & Bagus & Bagus & Sama \\
\hline 8 & Pepaya08 & 213 & 166 & 29 & 27 & 16 & Jelek & Jelek & Sama \\
\hline 9 & Pepaya09 & 123 & 137 & 64 & 15 & $\mathbf{8}$ & Jelek & Sedang & Beda \\
\hline 10 & Pepaya10 & 125 & 128 & 59 & 13 & 7 & Jelek & Jelek & Sama \\
\hline 11 & Pepaya11 & 110 & 121 & 52 & 18 & 10 & Jelek & Jelek & Sama \\
\hline 12 & Pepaya12 & 132 & 135 & 54 & 16 & 9 & Jelek & Jelek & Sama \\
\hline 13 & Pepaya13 & 122 & 134 & 58 & 21 & 11 & Sedang & Sedang & Sama \\
\hline 14 & Pepaya14 & 112 & 113 & 66 & 17 & 9 & Jelek & Jelek & Sama \\
\hline 15 & Pepaya15 & 174 & 187 & $\mathbf{6}$ & 27 & 11 & Bagus & Bagus & Sama \\
\hline
\end{tabular}




\begin{tabular}{|c|c|c|c|c|c|c|c|c|c|}
\hline No & Nama & Red & Green & $\begin{array}{c}\text { Defect } \\
(\text { persen })\end{array}$ & $\begin{array}{c}\text { Mayor } \\
(\mathbf{c m})\end{array}$ & $\begin{array}{c}\text { Minor } \\
(\mathbf{c m})\end{array}$ & $\begin{array}{c}\text { Hasil } \\
\text { Sistem }\end{array}$ & $\begin{array}{c}\text { Hasil } \\
\text { Pakar }\end{array}$ & $\begin{array}{c}\text { Ketera- } \\
\text { ngan }\end{array}$ \\
\hline 16 & Pepaya16 & 195 & 160 & 10 & 21 & 9 & Bagus & Jelek & Beda \\
\hline 17 & Pepaya17 & 169 & 180 & 7 & 30 & 14 & Bagus & Bagus & Sama \\
\hline 18 & Pepaya18 & 214 & 192 & 6 & 27 & 13 & Bagus & Bagus & Sama \\
\hline 19 & Pepaya19 & 190 & 187 & 10 & 31 & 15 & Bagus & Bagus & Sama \\
\hline 20 & Pepaya20 & 209 & 185 & 19 & 29 & 13 & Bagus & Jelek & Beda \\
\hline
\end{tabular}

Berikut merupakan Tabel 7 hasil pengujian fuzzy dengan pengujian oleh pakar tentang penentuan kualitas buah pepaya California. Kemudian dilakukan perhitungan untuk mendapatkan tingkat akurasi pentuan kualitas terhadap data uji menggunakan Confusion Matrix seperti Tabel 8 dan Tabel 9.

Tabel 7 Hasil Pengujian

\begin{tabular}{|c|c|c|c|c|}
\hline & \multicolumn{3}{|c|}{ Target } \\
\hline & & Jelek & Sedang & Bagus \\
\hline \multirow{3}{*}{$\stackrel{\bar{\Xi}}{\stackrel{E}{0}}$} & Jelek & 7 & 1 & 1 \\
\hline & Sedang & $\mathbf{0}$ & 1 & $\mathbf{0}$ \\
\hline & Bagus & 3 & 0 & 7 \\
\hline & Jumlah & 10 & 2 & 8 \\
\hline
\end{tabular}

Tabel 8 Confusion Matrix

\begin{tabular}{|c|c|c|c|c|}
\hline & TP & FP & FN & TN \\
\hline Jelek & $\mathbf{7}$ & $\mathbf{2}$ & $\mathbf{3}$ & $\mathbf{8}$ \\
\hline Sedang & $\mathbf{1}$ & $\mathbf{0}$ & $\mathbf{1}$ & $\mathbf{1 8}$ \\
\hline Bagus & $\mathbf{7}$ & $\mathbf{3}$ & $\mathbf{1}$ & $\mathbf{9}$ \\
\hline
\end{tabular}

Tabel 9 Evaluasi

\begin{tabular}{|l|c|c|c|}
\hline & Accuracy & Precision & Recall \\
\hline Jelek & $\mathbf{7 5 \%}$ & $\mathbf{7 8 \%}$ & $\mathbf{7 0 \%}$ \\
\hline Sedang & $\mathbf{9 5 \%}$ & $\mathbf{1 0 0 \%}$ & $\mathbf{5 0 \%}$ \\
\hline Bagus & $\mathbf{8 0 \%}$ & $\mathbf{7 0 \%}$ & $\mathbf{8 7 . 5 \%}$ \\
\hline
\end{tabular}

Dari penelitian ini didapatkan hasil bahwa dari 20 pepaya ada 15 pepaya yang dapat diklasifikasikan dengan benar. Persentasi yang diperoleh yaitu $75 \%$. Jika dihitung accuracy per kelas, pepaya dengan kualitas sedang dapat diklasifikasikan mencapai $95 \%$.

\section{SIMPULAN}

Pada penelitian yang dilakukan didapatkan hasil identifikasi mutu pepaya secara keseluruhan sebesar $75 \%$. Akurasi yang didapat untuk masingmasing pepaya yaitu pepaya jelek $75 \%$, pepaya sedang $95 \%$ dan pepaya bagus $80 \%$.

\section{DAFTAR PUSTAKA}

Al Rivan, M. E. and Suherman, J. (2020) 'Penentuan Mutu Buah Pepaya California (Carica Papaya L.) Menggunakan Fuzzy Mamdani', Elkha, 12(2), p. 76. doi: 10.26418/elkha.v12i2.41164.

Andono, P. N. and Sutojo, T. (2017) Pengolahan citra digital. Penerbit Andi.

Bakar, B. A. and Ratnawati, R. (2017) 'Petunjuk Teknis Budidaya Pepaya', Balai Pengkajian Teknologi Pertanian Aceh, p. 35.

Bon, A. T. and Utami, S. F. (2016) 'Applying fuzzy inference system tsukamoto for decision making in crude palm oil production planning', Proceedings of the International Conference on Industrial Engineering and 
Operations Management, 8-10 March, pp. 2206-2210.

Mazenda, G., Andy Soebroto, A. and Dewi, C. (2014) 'Implementasi Fuzzy Inference System (Fis) Metode Tsukamoto Pada Sistem Pendukung Keputusan Penentuan Kualitas Air Sungai', Journal of Enviromental Engineering and Sustainable Technology, 1(2), pp. 92-103. doi: 10.21776/ub.jeest.2014.001.02.4.

Murdianingsih, Y. and Utomo, L. T. (2016) 'SISTEM PENENTUAN KUALITAS SINGKONG UNTUK BAHAN BAKU KERIPIK DENGAN METODE FUZZY TSUKAMOTO ( Studi Kasus Kampung Kaliwadas )', Jurnal Teknologi Informasi dan Komunikasi, pp. 2252-4517.

Pandey, R., Gamit, N. and Naik, S. (2014) 'A novel non-destructive grading method for Mango (Mangifera Indica L.) using fuzzy expert system', in 2014 International Conference on Advances in Computing, Communications and Informatics (ICACCI), pp. 1087-1094. doi: 10.1109/ICACCI.2014.6968366.

Prahara, H. W. and Sela, E. I. (2016) 'Tingkat Kematangan Buah Pepaya Dengan Jaringan Syaraf Lvq', Seminar Riset Teknologi Informasi (SRITI) tahun, pp. 388391.

Sari, N. R. and Mahmudy, W. F. (2015) 'Fuzzy Inference System Tsukamoto Untuk Menentukan Kelayakan Calon Pegawai',
Seminar Nasional Sistem Informasi Indonesia (SESINDO), (November), pp. 245-252.

Sugiyanto, S. and Wibowo, F. (2015) 'Klasifikasi Tingkat Kematangan Buah Pepaya ( Carica Papaya L ) California ( Callina-Ipb 9 ) Dalam Ruang Warna Hsv', prosiding SENATEK, 1(November), pp. 335-341.

Sutojo, T., Mulyanto, E. and Suhartono, V. (2011) Kecerdasan Buatan. Yogyakarta: Andi Offset.

Syakry, S. A., Mulyadi, M. and Simbolon, Z. K. (2015) 'Buah Menggunakan Fuzzy C-Means ( Fcm ) Clustering', Jurnal Penelitian Teknik Informatika, 7(2), pp. 150-169. doi: https://doi.org/10.29103/techsi.v7i 2.199 .

Syakry, S. S. A. and Mulyadi, M. (2013) 'Analisis Tingkat Kandungan Nilai Warna untuk Penentuan Tingkat Kematangan pada Citra Buah Papaya callina', JURNAL ILMIAH ELITE ELEKTRO, 4, pp. 31-37.

Usmayani, S. N., Basuki, E. and Yasa, I. W. S. (2015) 'PENGGUNAAN KALIUM PERMANGANAT $\left(\begin{array}{lll}\mathrm{KMnO} & 4\end{array}\right)$ PADA PENYIMPANAN BUAH PEPAYA CALIFORNIA (Carica papaya L.) [The Use of Potassium Permanganate (KMnO 4 ) On Shelf Life of California's Papaya (Carica papaya L.)]', Jurnal Ilmu dan Teknologi Pangan), 1(2), pp. 48-55. 